\title{
Key Drivers for Adopting Design-Build in Public Construction Projects: Malaysian Perspective
}

\author{
"Zheng Ping Lee1, Rahimi A. Rahman",2 and Shu Ing Doh³
}

\begin{abstract}
First submission: 3 March 2020; Accepted: 12 August 2020; Published: 30 July 2021
To cite this article: Zheng Ping Lee, Rahimi A. Rahman and Shu Ing Doh (2021). Key drivers for adopting design-build in public construction projects: Malaysian perspective. Journal of Construction in Developing Countries, 26(1): 131-160. https://doi.org/10.21315/jcdc2021.26.1.7.
\end{abstract}

To link to this article: https://doi.org/10.21315/jcdc2021.26.1.7

\begin{abstract}
Design-build (D-B) had been applied in many advanced countries because the delivery method improves construction project success. While several megaprojects in Malaysia have adopted D-B, it is still uncommon in the local construction industry. Therefore, understanding the key drivers that are affecting the acceptance or rejection of D-B is crucial. However, that information is lacking in the existing body of knowledge. Thus, this research addresses that issue by identifying the key drivers for adopting $D-B$ in the Malaysian construction sector from the standpoint of the core project parties (e.g., project clients, consultants and contractors). Questionnaire survey data from 111 professionals with D-B experience were analysed using inferential statistics, including t-test and analysis of variance (ANOVA). The outcome shows that the key drivers for industry practitioner in Malaysia for adopting D-B are: (1) "Maximise the use of resources between project team members", (2) "Sharing of expertise (design and technical) with project team members", (3) "Well-organised project team structure", (4) "High success rate" and (5) "Dispute prevention during the construction stage". Also, there are no significant differences found in the drivers between different geographical regions and project parties. Based on the investigations, this study adds to the current assortment of information in capturing the key drivers and providing an in-depth understanding of the underlying components for adopting D-B in Malaysia. Researchers and industry practitioners can use the findings to enhance the level of D-B adoption strategically.
\end{abstract}

Keywords: Construction industry, Design-build, Drivers, Developing countries, Public projects

\section{INTRODUCTION}

The construction industry assumes a critical job in the nation's gross domestic product (GDP), financial action, government income, private venture and employment. According to Khan, Liew and Ghazali (2014), construction industries play an important role in generating a positive economy for Malaysia. They also reported that there is a strong relationship between the construction industry and economic growth in Malaysia. As a 2018 annual report by the Department of Statistic Malaysia, the value of gross output in 2017 registered a yearly growth rate of $7.2 \%$ to MYR204.4 billion as compared to 2015, MYR177.9 billion. Likewise, successful construction projects can spike economic development and improvement, while a failure can set a nation's advancement back for many years (Merrow, 2011; Ofori, 2018). However, construction projects are defying negative

\footnotetext{
'Faculty of Civil Engineering Technology, Universiti Malaysia Pahang, Pahang, MALAYSIA 'Earth Resources and Sustainability Centre, Universiti Malaysia Pahang, Pahang, MALAYSIA ${ }^{3}$ College of Engineering, Universiti Malaysia Pahang, Pahang, MALAYSIA

*Corresponding author: alexzplee@gmail.com
} 
outcomes due to various reasons, including lack of planning and scheduling, lack of communication between parties, inefficient decision-making processes, inside regulatory techniques and administrative procedures and bureaucracy within project organisations (Levin, 2016). Accurately construction projects depend on the incorporated exertion of several hierarchically linked parties (e.g., architects, engineers, surveyors, general contractors, subcontractors and suppliers). These parties generally maintained autonomous relationships with discrete objectives and goals in accordance to board styles and standard operating procedures (Gudienè et al., 2013). Also, given the fragmented nature of construction, communication and coordination problems are quite common and can impact project performance and productivity (Chen et al., 2012).

Similar to other developing countries, the Malaysian construction industry is facing many issues, namely fragmentation, complexity, dynamism and lack of standardisation, which demands a more integrated approach (Hwang and Lim, 2013). Specifically, contractors are facing a lack of awareness of site staff, insufficient skilled personnel and insufficient time. The issues related to mindfulness and abilities of staff are essential ones in the case recognisable proof procedure (Hashim et al., 2015). Also, construction staffs are relied upon to completely carryout the contract arrangements and furthermore, they are also burdened with a heavy workload and this contributes to the slow development in the Malaysian construction industry (Jaafar and Nuruddin, 2012). A prior study suggests that these issues are occurring due to improper selection of appropriate procurement methods caused a high tendency for project delay, cost overrun, poor work quality and diminishing the robustness and cohesion of the project's team spirit in the Malaysian construction industry (Khairulzan and Nabilah, 2015). Hence, it is essential to identify suitable procurement methods to facilitate the integration of the numerous stakeholders of construction projects.

A recent study identified that project integration could directly improve construction project performance (Demirkesen and Ozorhon, 2017). Amidst the improvement in construction project, Design-Build (D-B) allows for a single entity to comprise of a team or consortium to simplify construction tasks by providing project owners having a contractual relationship for both the design and construction as a single entity (Braimah, 2014; Demirkesen and Ozorhon, 2017). Generally, D-B, as an alternative procurement method, can overcome the incompleteness of Design-Bid-Build (D-B-B) in delivering construction projects. Numerous studies have concurred that D-B can deliver fast track and highly complex projects (Yongqiang, Xingyu and Ning, 2013; Khan, 2014). Also, construction projects are adopting D-B due to several reasons, including the adoption of innovative procurement approaches in the public sector projects (Kinkel and Som, 2010; Hassanien and Dale, 2012) with better communication between project parties that results in higher project success (Chatterjee, 2012; Salim and Sulaiman, 2013). Moreover, large megaprojects in Malaysia have adopted D-B, including the Petronas Twin Towers (KLCC), Kuala Lumpur International Airport (KLIA), Malaysia North-South Highway, and Penang Bridge (Jaafar and Nuruddin, 2012; Gomez and Gambo, 2016). Thus, other project stakeholders are also considering the adoption of D-B in their construction projects.

However, improper selection of construction procurement approaches commonly contributes to project failure (Chan et al., 2016). In other words, the criteria for selecting different procurement strategies may be country-specific and to believe that the circumstances are similar may be a recipe for failure. 
For instance, the uprising structures plan complexity, the demand for progressively proficient financial management, the need to reduce design and development time durations and the growing burden of contract administration have placed added pressure and demand on clients to find alternative ways to the traditional method of procurement (Khoshgoftar, Bakar and Osman, 2010). Also, while prior studies provide useful insights into the implementation of D-B in both theory and practice, but projects may not select the D-B method given the project parties, due to the refusal of the client, consultant and/or contractor (Palaneeswaran and Kumaraswamy, 2000). In Singapore, Ofori (2018) showed that the important D-B drivers for adopting new and existing buildings are returning on investments, local and overseas competitions, lesser work variations and marketing/branding motive. Furthermore, the most important drivers of large D-B construction projects in Vietnam are better pricing, early involvement from construction parties and better construction waste planning (Le-Hoai, Lee and Nguyen, 2013). In other words, having a better understanding of the drivers for adopting D-B (hereafter DBDs) can play a vital role in promoting the broader adoption of D-B in developing countries (Darko et al., 2017a). Therefore, understanding the DBDs that influence the project parties' decision to accept or decline D-B is crucial.

Accordingly, the objective of this study is to identify the key drivers for adopting D-B in the Malaysian construction industry. To achieve this objective, this paper addresses the research questions related to what are the attributes of the main drivers for D-B adoption. The authors answer the questions by analysing a set of questionnaire survey data collected from industry practitioners using descriptive statistics, normalisation method, one-way analysis of variance (ANOVA) and factor analysis. As such, this research enhances D-B in several ways. First, the study provides an understanding of the relevant drivers for $D-B$ adoption, which is necessary for guiding the D-B adoption decision making of key project parties. Also, the research findings can assist industry practitioners and researchers create promotion strategies that encourage the widespread adoption of D-B to achieve high buildability construction projects. In other words, the contributions and impact of this study will, therefore, allow project practitioners to make informed decisions when deciding between adopting or rejecting the adoption of D-B for their construction projects.

\section{LITERATURE REVIEW}

\section{Drivers for Adopting D-B}

Procurement selection has received significant attention from researchers in recent years for developed countries such as the United Kingdom (UK) and the United States (US) (Aljohani, 2017). D-B adoption in the UK construction industry is more than $43 \%$ compared to other methods of procurement (Rowlinson and McDermott, 2013). For the US, D-B has experienced rapid growth from less than $10 \%$ in the 1980 s to $23 \%$ by 1990 and further increased to more than $30 \%$ and $48 \%$ in 2000 and 2018 , respectively (DBIA [Design Build Institute of America], 2018). Interestingly, both countries share similar motivating drivers for adopting $D-B$, which is to avoid delays, reduce costly claims, avoid litigations, single-point responsibility, avoid design discrepancies and lower construction risks (Choudhry et al., 2017). 
Most Asian countries, such as China, Vietnam, Indonesia and Singapore, have adopted D-B into public sector projects (Le-Hoai, Lee and Lee, 2008; Smith, 2014; Marzuki et al., 2019). However, in Japan, D-B is predominantly applied in both public and private sector projects due to the high capability of D-B contractors in providing full design and construction services as well as acquiring a risk-taking attitude of large and complex construction projects (Ando, 2011; Saito, 2015; Ando, 2016). Before the year 2000, the adoption of D-B in China starts with on an ad-hoc basis (Lam, Chan and Chan, 2008). Since then, the D-B procurement method has been accepted by most construction industry practitioners in the past three years (Chan et al., 2016). The game-changer for D-B implementation in China resulted from the success of projects such as 10 Airport Core Program Projects, Tsing Ma Bridge, Kap Shui Mun Bridge and Ma Wan Viaducts (Lam, Chan and Chan, 2008).

Also, other drivers for adopting D-B include the sharing of expertise, risk transfer, good company portfolio, reduced communication barriers, minimised disputes and competitive project pricing for clients (Chan et al., 2016; Moza and Paul, 2018). A summary of the main drivers for adopting D-B from the existing literature is shown in Table 1. All the reference above is based on the sequence in the bibliography. While the exhibit shows there are 16 main drivers, it also shows that different drivers are motivating project stakeholders in adopting D-B in different nations. Specifically, predicting the drivers for adopting D-B in a country is difficult due to the placement of different project risks and allocation of responsibilities on construction project parties (Gibb and Isack, 2003). Therefore, as shown in Figure 1, a theoretical framework is proposed based on the relationship between low D-B adoption, identification of the key D-B drivers and eventually, to ensure better adoption of $D-B$ for the successful construction projects.

Table 1. Drivers for Adopting D-B

\begin{tabular}{|c|c|c|}
\hline Code & D-B Drivers & Source \\
\hline DBD_1 & $\begin{array}{l}\text { Maximise the use of } \\
\text { resources between } \\
\text { project team members }\end{array}$ & $\begin{array}{l}\text { Lam and Wong (2009), Cheung, Wong and } \\
\text { Lam (2012), Mao et al. (2015), Bagaya and } \\
\text { Song (2016), Khairuddin (2016), Osei-Kyei and } \\
\text { Chan (2017) and Moza and Paul (2018) }\end{array}$ \\
\hline DBD_2 & $\begin{array}{l}\text { Share expertise (design } \\
\text { and technical) with } \\
\text { project team members }\end{array}$ & $\begin{array}{l}\text { Ling and Kerh (2004), Le-Hoai, Lee and Lee, } \\
\text { (2008), Hassanien and Dale (2012), Wong } \\
\text { et al. (2014), Bagaya and Song (2016), } \\
\text { Khairuddin (2016) and Lamont (2016) }\end{array}$ \\
\hline DBD_3 & $\begin{array}{l}\text { Greater responsibility } \\
\text { for contractors to } \\
\text { communicate with } \\
\text { other team members }\end{array}$ & $\begin{array}{l}\text { Hwang and Lim (2013), Gudienè et al. (2013), } \\
\text { Osborne (2015), Bagaya and Song (2016) and } \\
\text { Osei-Kyei and Chan (2017) }\end{array}$ \\
\hline DBD_4 & $\begin{array}{l}\text { Dispute prevention during } \\
\text { the construction stage }\end{array}$ & $\begin{array}{l}\text { Nitithamyong and Tan (2007), Ling and Leong } \\
\text { (2012), Lam, Chan and Chan (2006), Osborne } \\
\text { (2015), Behr (2017) and Moza and Paul (2018) }\end{array}$ \\
\hline DBD_5 & $\begin{array}{l}\text { Interest in the design-build } \\
\text { approach }\end{array}$ & $\begin{array}{l}\text { Chen et al. (2012), Gudienè et al. (2013), } \\
\text { Akintoye (2014), Li et al. (2014), Hidenori (1995) } \\
\text { and Osei-Kyei and Chan (2017) }\end{array}$ \\
\hline
\end{tabular}


Table 1. Continued

\begin{tabular}{|c|c|c|}
\hline Code & D-B Drivers & Source \\
\hline DBD_6 & $\begin{array}{l}\text { Greater allocation of risks } \\
\text { to contractors }\end{array}$ & $\begin{array}{l}\text { Ling and Kerh (2004), Nitithamyong and Tan } \\
\text { (2007), Lam, Chan and Chan (2006), Osborne } \\
\text { (2015), Bagaya and Song (2016) and Moza } \\
\text { and Paul (2018) }\end{array}$ \\
\hline DBD_7 & High success rate & $\begin{array}{l}\text { Songer and Molenaar (2007), Ling and Kerh } \\
\text { (2004), Chan et al. (2010), Hwang and Lim } \\
\text { (2013), Bogus, Migliaccio and Jin (2013), Lam, } \\
\text { Chan and Chan (2008), Khairuddin (2016), } \\
\text { Aljohani (2017), Osei-Kyei and Chan (2017) } \\
\text { and Ofori (2018) }\end{array}$ \\
\hline DBD_8 & Reduce works variations & $\begin{array}{l}\text { Chan and Yu (2005), Bogus et al. (2013), } \\
\text { Gudiene et al. (2013), Hassanien and Dale } \\
\text { (2012), Ling and Leong (2012), Kerzner (2014), } \\
\text { Khalfan et al. (2014), Osei-Kyei and Chan } \\
\text { (2017) and Durdyev and Hosseini (2020) }\end{array}$ \\
\hline DBD_9 & $\begin{array}{l}\text { Improve tendering } \\
\text { procedures }\end{array}$ & $\begin{array}{l}\text { Moore and Dainty (2001), Ling and Kerh } \\
\text { (2004), Hamzah et al. (201 1), Wall (1993), } \\
\text { Khairulzan and Nabilah (2015), Behr (2017) } \\
\text { and Durdyev and Hosseini (2020) }\end{array}$ \\
\hline DBD_10 & Better track record & $\begin{array}{l}\text { Ling and Leong (2012), Bogus et al. (2013), } \\
\text { Kerzner (2014), Osei-Kyei and Chan (2017) } \\
\text { and Moza and Paul (2018) }\end{array}$ \\
\hline DBD_11 & Better project pricing & $\begin{array}{l}\text { Le-Hoai, Lee and Lee (2008), Chan et al. } \\
\text { (2010), Cheung, Wong and Lam (2012), Bogus } \\
\text { et al. (2013), Gudiene et al. (2013), Khalfan } \\
\text { et al. (2014), Khairulzan and Nabilah (2015), } \\
\text { Khairuddin (2016), Behr (2017), Osei-Kyei and } \\
\text { Chan (2017), Ofori (2018) and Lee, Rahman } \\
\text { and Doh (2020) }\end{array}$ \\
\hline DBD_12 & $\begin{array}{l}\text { Create a win-win } \\
\text { situation between } \\
\text { project stakeholders }\end{array}$ & $\begin{array}{l}\text { Moore and Dainty (2001), Cheung, Wong } \\
\text { and Lam (2012), Hassanien and Dale (2012), } \\
\text { Hwang and Lim (2013), Bagaya and Song } \\
\text { (2016) } \\
\text { and Lamont (2016) }\end{array}$ \\
\hline DBD_13 & $\begin{array}{l}\text { Early contractor } \\
\text { involvement in the } \\
\text { design stage }\end{array}$ & $\begin{array}{l}\text { Lam (2004), Chen and Chen (2007), Bogus et } \\
\text { al. (2013), Kerzner (2014), Ling and Liu (2014), } \\
\text { Hashim et al. (2015), Darko, Zhang and Chan } \\
\text { (2017), Ozorhon and Karahan (2016) and } \\
\text { Marzuki et al. (2019) }\end{array}$ \\
\hline DBD_14 & $\begin{array}{l}\text { Capable to provide clients } \\
\text { with a guaranteed cost }\end{array}$ & $\begin{array}{l}\text { Chan et al. (2010), Khoshgoftar, Bakar and } \\
\text { Osman (2010), Hemlin (1994), Kinkel and } \\
\text { Som (2010), Ling and Leong (2012), Hashim } \\
\text { et al. (2015), Darko, Zhang and Chan (2017), } \\
\text { Aljohani (2017), Osei-Kyei and Chan (2017), } \\
\text { Ofori (2018) and Tsiga, Emes and Smith (2016) }\end{array}$ \\
\hline
\end{tabular}


Table 1. Continued

\begin{tabular}{lll}
\hline Code & D-B Drivers & Source \\
\hline DBD_15 & $\begin{array}{l}\text { Capable of providing } \\
\text { Clients with a guaranteed } \\
\text { fixed schedule }\end{array}$ & $\begin{array}{l}\text { Moore and Dainty (2001), Ling and Kerh } \\
\text { (2004), Hemlin (1994), Bogus et al. (2013) and } \\
\text { Li et al. (2014) }\end{array}$ \\
$\begin{array}{ll}\text { Well-organised project } \\
\text { team structure }\end{array}$ & $\begin{array}{l}\text { Ling and Kerh (2004), Bogus et al. (2013), Salim } \\
\text { and Sulaiman (2013), Khan (2014), Lam, Chan } \\
\text { and Chan (2008), Hashim et al. (2015), Denti } \\
\text { and Hemlin (2012), Ozorhon and Karahan } \\
\text { (2016) and Chakra and Ashi (2019) }\end{array}$ \\
& &
\end{tabular}

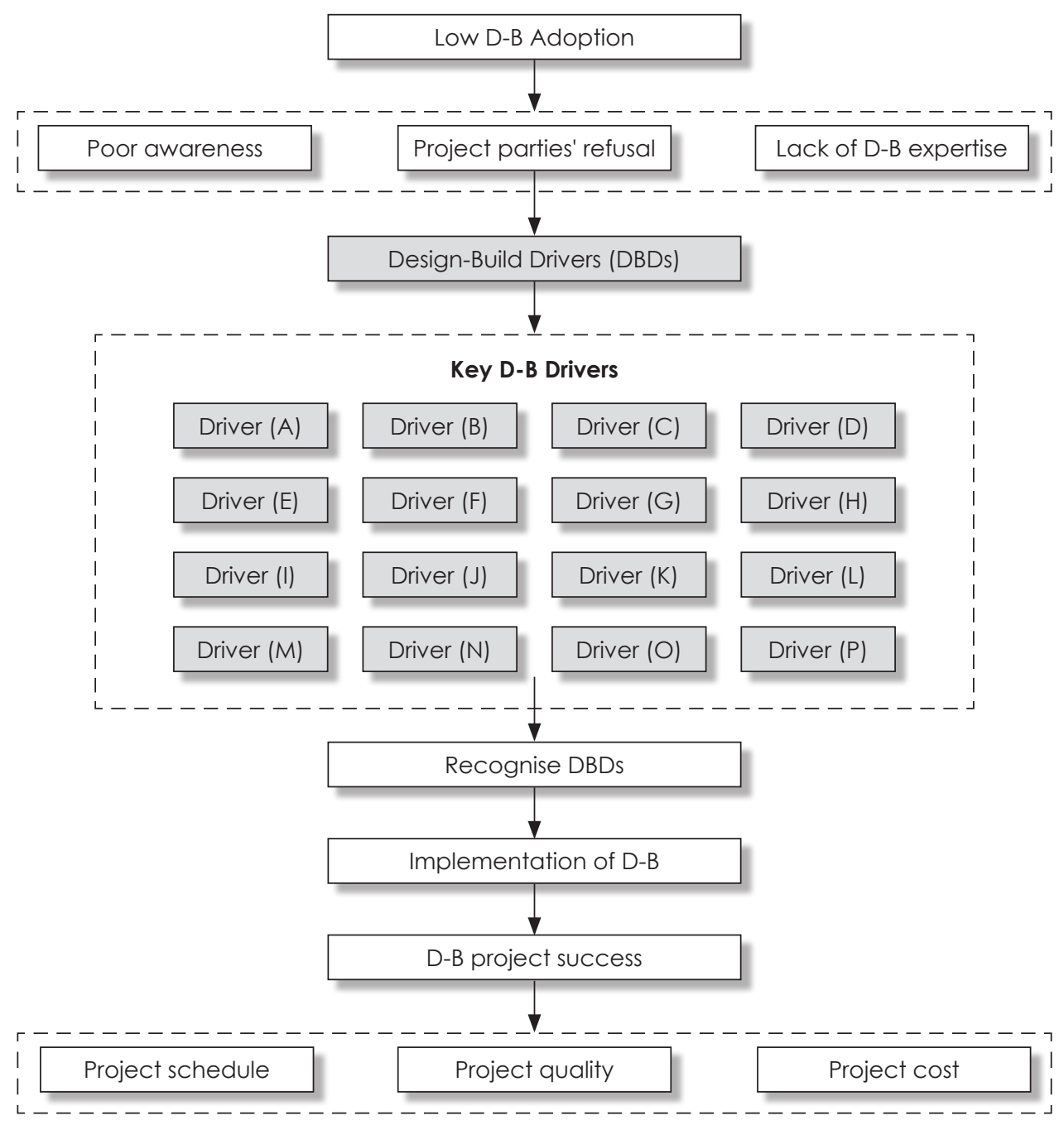

Figure 1. The Theoretical Framework for D-B 


\section{D-B Adoption in Malaysia}

For many years, construction practitioners and researchers in Malaysia are pursuing innovations to address and overcome the problems in construction projects since having appropriate procurement strategies is necessary to support project success in the local construction sector (Moza and Paul, 2018). Therefore, one study has highlighted the importance of adopting D-B in Malaysia in integrating project team members, creating a good reputation and image amongst project participants and optimizing the value of projects (Hashim et al., 2015). Also, another study suggests that enhancing D-B adoption in Malaysia is crucial to prioritise the selection of construction professionals, such as contractors and consultants, in facilitating better project success (Halil et al., 2018). Also, another study has identified the success factors for implementing designbuild in public construction projects through interviewing industry practitioners (Lee, Rahman and Doh, 2020). However, the existing body of knowledge in this field lacks information regarding key drivers for adopting D-B from the perspective of the Malaysian construction industry.

\section{Positioning This Study}

Adopting a novel approach in the procurement, contracting and management of construction projects requires significant organisational changes to assist the structure of the organisation in learning new practices while disengaging from traditional methods (Papajohn, El Asmaar and Molenaar, 2019). Accordingly, this study identifies the drivers that influence the main parties in their decision to adopt D-B in projects. Furthermore, this study reveals that the existing body of knowledge offers limited information regarding DBDs in the context of the Malaysian construction industry. Therefore, this study closes this gap by identifying the key DBDs for D-B adoption in the Malaysian construction industry from the perspective of the main project parties (i.e., project clients, consultants and contractors).

\section{METHODOLOGY}

To identify the DBDs apposite for D-B public projects in the Malaysian construction industry, the development of the questionnaire survey in this study uses a two-step procedure to finalise the questions before distributing the survey to respondents. Various statistical analyses, including descriptive means with normalisation, mean ranking, one-way analysis of variance (ANOVA) and factor analysis, are employed to analyse the collected data. Figure 2 illustrates the approaches in conducting this research.

\section{Development of the Questionnaire Survey}

The design and development of the measurement items and the questionnaire are constructed according to the guidelines as mentioned in prior construction management related research (Misangyi et al., 2006; Wong, Chan and Wadu, 2016; Hwang et al., 2017). In establishing the content validity of the questionnaire instrument, first, in-depth interviews are conducted with various industry 
professionals such as architects, engineers, surveyors, corporate members, building and infrastructure contractors in Malaysia. This procedure suggested by Hair et al. (2007) is adopted to establish the content validity of the measures in this study. These parties provided their comments and views of current trends in the construction industry in Malaysia and suggested major drivers that could help to motivate stakeholders to adopt D-B based on their knowledge and on-site experiences. This information is used to resolve any mismatch between theoretical studies and actual practices.

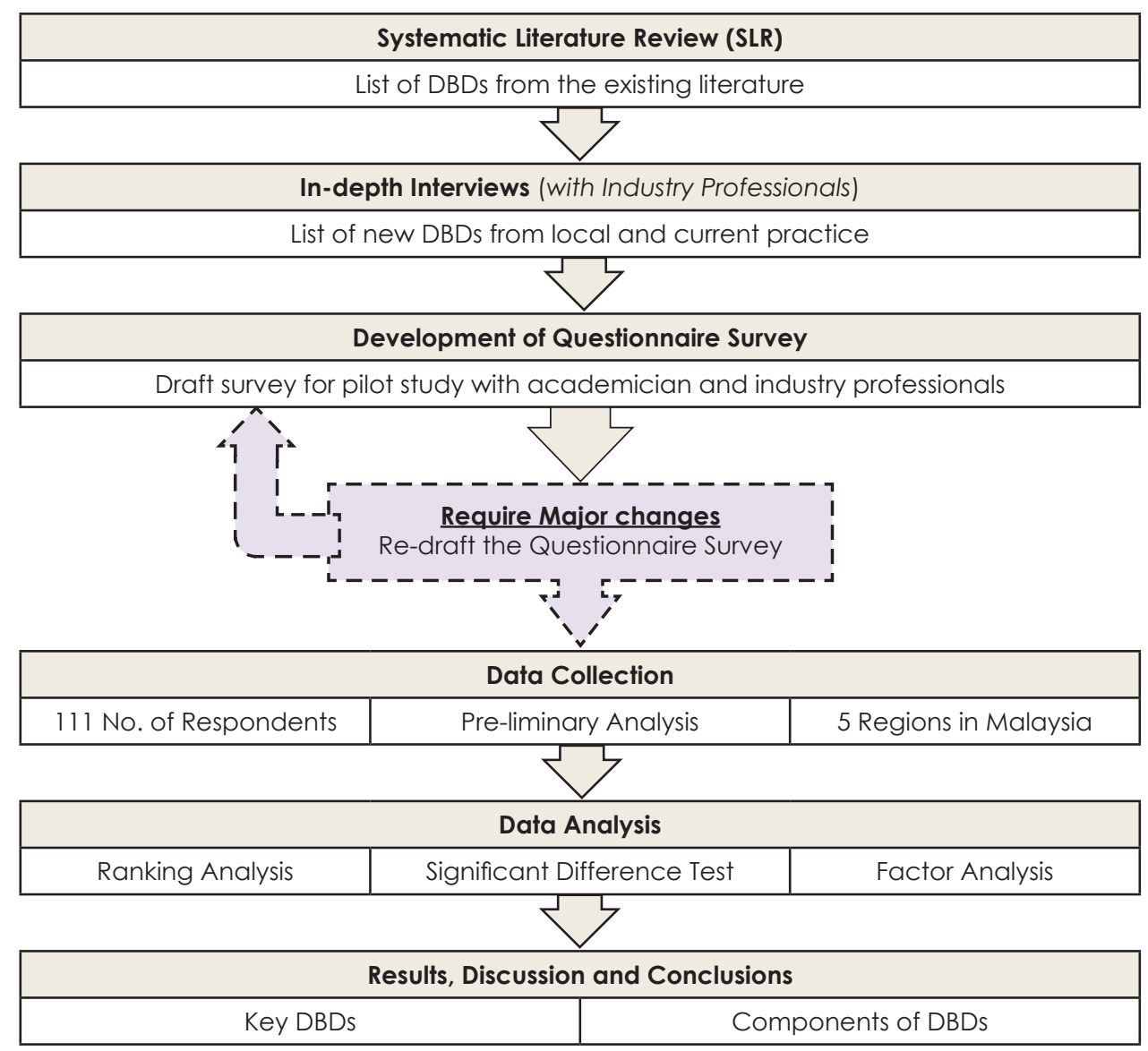

Figure 2. A Research Framework for the Study

Next, the initial draft of the survey is revised based on information from this study's systematic literature review. The review involves searching articles that have two or more of the following keywords: "design-build" or "construction" and "construct" or "D-B projects". From the list of 220 articles reviewed, 16 drivers for adopting D-B is established as shown in Table 1. 
To finalise the questionnaire survey, a pilot study is conducted on the list of drivers for adopting D-B to validate and test the completeness and coverage of the survey (Li et al., 2014). The pilot study involves three individuals - a professor, a professional architect and a corporate member for construction development that are all knowledgeable in the research topic with in-depth theoretical understanding and practical experience of more than 10 years. The individuals are requested to evaluate whether the set of drivers is appropriate and whether any drivers should be added or eliminated. The pilot study approach is adopted to develop pertinent lines of questions and to provide conceptual clarification for the research (Yazan, 2014). In other words, those individuals can provide concluding refinement opportunities to develop an informative, clear and wellstructured survey.

In designing the questionnaire, the researcher was aware that a questionnaire that consists of multiple pages would lead to dishonesty answer and the respondent will easily distracted (Melzack, 1987; Hugick and Best, 2008; Gogol et al., 2014). Therefore, in this questionnaire, the researcher comprised respondent profile and demographic at first page and selection of key drivers for adopting $D-B$ in Malaysia questionnaire in the following pages. Apart from that, the researcher chose to use the English language as a first language in constructing the questionnaire to avoid back to back translation that might jeopardise the meaning of each questionnaire (Behr, 2017).

The finalised questionnaire instrument required respondents to rate the 16 drivers in regard to D-B adoption in the Malaysian construction industry. A 5-point Likert scale rating is used to collect the perceptions of the respondent in measuring the continuum from one extremely important value to the other with an equal number of positive and negative responses and one neutral category (Rea and Parker, 2014). The reason that the researcher used a 5-point Likert scale rating is to make it easy to analyse and it is more specific, although a 7/10-point scale gives more independence to the respondent to choose. However, it is complicated to analyse the results (Dawes, 2008). Also, using a 5 -point Likert scale rating is the simplest way and to the respondent and the researcher (MCLeod, 2019). Spaces are also provided at the end of the 16 drivers to allow the respondent to add additional drivers to the study (Labaw, 1980).

\section{Data Collection}

In conducting this study, an empirical questionnaire survey is used to collect the professional views of respondents on the drivers for adopting D-B in Malaysia. The survey's target population consists of industry practitioners with knowledge, experience and understanding of D-B adoption in Malaysia. As there is no sampling frame for this study, the sample is a nonprobability sample (Zhao, Shen and Zuo, 2015; Darko et al., 2017b). This sampling technique is utilised to acquire a representative sample and is appropriate when an utterly random sampling method cannot be used to select respondents from the whole population (Pacheco, Ordonez and Martínez, 2012). Whereas, the respondents can be selected based on their willingness to take part in the research (Wilkins, 2011). Thus, a snowball sampling method is used in this study to obtain a correct and effective overall sample size, which has also been used in previous construction management studies (Zhang, Shen and Wu, 201 1; Mao et al., 2015). Similarly, local companies in the construction of D-B projects in Malaysia are approached to 
participate in the study. This is equally important as many of these organisations had adopted D-B into their projects which enabled them to have a clear understanding of the features that distinguish the D-B procurement approach from other known procurement approaches.

Initially, in identifying respondents to partake in this study, the Malaysian construction industry database is used to identify potential and knowledgeable respondents. By adopting this approach, 123 survey questionnaires are disseminated and administered to collect responses from clients/developers, consultants and contractor companies. Following the two waves of collecting data and one reminder, 111 sets of questionnaires with valid responses are returned, yielding a $90.2 \%$ response rate. While this figure can be lower since the online survey can be shared and therefore untraceable, the authors believe this response rate is acceptable as there were no requesting respondents sharing the survey to other individuals. Nevertheless, a rate from a $75 \%$ to $100 \%$ rate is an acceptable range to proceed with the research (Eriksson, 2017). Although the sample size is relatively small, statistical analyses could still be undertaken. According to the commonly accepted rule of thumb, having a sample size of 30 or above, the central limit theorem holds (Ott and Longnecker, 2010; Hwang et al., 2015). Also, because the adoption of the D-B procurement approach in the Malaysian construction industry is relatively low (El-Karim, El Nawawy and AbdelAlim, 2017), the number of experienced respondents in D-B projects is limited. Finally, the sample size can be considered as sufficient as other constructionrelated studies are using a smaller sample size (Shen, Zhang and Zhang, 2016; Zhao, Hwang and Lee, 2016).

\section{Data Analysis}

The data analysis starts with determining the Cronbach's alpha coefficient to measure internal consistency. Cronbach's alpha coefficient value should be higher than the threshold of 0.70 (Taber, 2018). Cronbach's alpha for this study is 0.876 . Thus, the data is further analysed as presented in the following subsections.

\section{Analysis of Variance (ANOVA)}

One-way ANOVA (a) is a suitable method for comparing the mean scores of more than two groups (Misangyi et al., 2006). In this study, ANOVA is used to check the significant differences in means from the three respondent groups (client, consultant and contractor) and the different regions in Malaysia. The one-way ANOVA analysis for the means of different regions of northern, central, southern, eastern and east Malaysia revealed no significant differences. As such, the locations of the survey did not affect the responses. This study also found that there are no differences between the client-consultant (CL-CS), client-contractor (CL-CT) and consultant-contractor (CS-CT) as well as for the respondent groups with D-B experience and respondents without D-B experience. In other words, the relationship between the groups is statistically insignificant. Hence, all respondents groups (client, consultant and contractor) are combined in the subsequent analyses. 


\section{Mean Score Ranking}

This study uses the mean score ranking technique to rank the 16 drivers for adopting $D-B$ because the approach is widely used in the construction management research domain to rank the relative importance of specific items. A total of 111 survey results are analysed to generate the total frequencies, mean and standard deviation (SD). Then, the items are then ranked according to the mean score values. If two or more drivers have identical mean scores, the highest rank is assigned to drivers with the lowest SD.

\section{T-Test}

The statistical $t$-tests of the mean values are used to ascertain whether each driver is significantly important. The one-sample t-test is conducted at a $95 \%$ confidence level with a $0.05 \mathrm{p}$-value. From this analysis, all 16 drivers had $p$-values lower than 0.05 . This result suggests that all 16 drivers are significantly important in driving and shaping $D-B$ in the Malaysian construction industry.

\section{Normalisation}

The min-max normalisation method, which normalised each column of a dataset to the interval $(0,1)$ (Campos et al., 2016; Goldstein and Uchida, 2016). Accordingly, this paper uses the normalisation method to determine the most important driver. To do that, each column $x$ is transformed to $x-\min (x) / \max (x)-$ $\min (x)$ where $\min (x)$ and $\max (x)$ represented the minimum and maximum values of $x$, respectively. Then, drivers with a normalised value of $\geq 0.50$ are considered as the most important drivers. This approach is used in various studies in the construction realms to identify a set of key variables, such as identifying the key drivers for adopting building information modelling in construction projects (Won et al., 2013), main drivers for risk management in construction companies (Zhao, Shen and Zuo, 2015), critical success factors of construction projects (Tsiga, Emes and Smith, 2016) and key drivers for adopting D-B adoption among different project stakeholders (Lee, Rahman and Doh, 2020).

\section{Factor Analysis}

Factor analysis is a data reduction technique which is used to identify underlying variables in explaining a similar trend of correlation in a set of observed variables and then groups the factors from large number to a smaller and more relevant set of factors or components. Based on the t-test analysis result, the 16 DBDs are statistically significant. Thus, exploratory factor analysis (EFA) used to explore the underlying drivers. However, before applying this method, the appropriateness of the data needed to be examined. Therefore, to proceed with this analysis, the Kaiser-Meyer-Olkin test (KMO) and Bartlett's test of sphericity are used to determine the suitability of the data for factor analysis. The KMO measures the sampling adequacy by comparing the size of the partial correlation coefficients and Bartlett's test of sphericity checks the presence of correlation among a set of variables. The results of the tests are presented in Table 2. The Bartlett's test of sphericity result of 294.894 with an associated level of significance of 
0.00 suggested that the correlation matrix is not an identity matrix (SPSS, 1997; Pallant, 2020). The KMO value of 0.786 is higher than the acceptable threshold of 0.50 (Kaiser, 1970), indicating that the sample is acceptable for factor analysis. Therefore, the data are suitable for factor analysis.

Table 2. Results of the Kaiser-Meyer-Olkin and Bartlett Test

\begin{tabular}{llr}
\hline Test & Item & Results \\
\hline Kaiser-Meyer-Olkin & The measure of sampling adequacy & 0.786 \\
Bartlett's test of sphericity & Approx. chi-square & 294.894 \\
& Df & 55.000 \\
& Sig. & 0.000 \\
\hline
\end{tabular}

For factor extraction, components with eigenvalues greater than one are extracted, which include company-related forces, cost-related forces and industry-related forces. The factor loading measures the correlation coefficient between an original variable and an extracted component. The requirement for factor loading items should be above 0.50 (Osborne, 2015); otherwise, it is regarded as insignificant (Li et al., 2014). As a result, low loading variables less than 0.50 are deleted.

\section{RESULTS AND DISCUSSIONS}

\section{Respondents Profile}

Table 3 summarises the respondent profiles of the survey. Regarding D-B public project experience, the experience of the respondents with having between 6 and 10 projects, 11 to 15 projects and 16 to 20 projects are 13 (11.7\%), 4 (3.6\%) and $4(3.6 \%)$, respectively. In other words, the majority of the respondents have experience in D-B projects. On the other hand, the majority of respondents 197 , $87.3 \%$ ) had more than 10 years' experience in the construction industry, whereas only 14 respondents (12.6\%) had between 1 and 9 years experience and no respondents with nil construction industry experience in this study. Therefore, while some of the respondents might not have any experience in D-B projects, the respondents consist of experienced practitioners in the industry that can provide appropriate insights to the study.

\section{Key Drivers for Adopting D-B in Malaysia}

Table 4 indicates that the mean scores for DBDs amongst the three groups of stakeholders ranged between 3.69 and 4.72. From the results of the normalisation, the key DBDs are: (DBD_1) "Maximise the use of resources between project team members", (DBD_2) "Sharing expertise (design and technical) with project team members", (DBD_16) "Well-organised project team structure", (DBD_7) "High success rate" and (DBD_4) "Dispute prevention during the construction stage". These DBDs are discussed in the following subsections. 
Table 3. Characteristics of the Survey Respondents

\begin{tabular}{llcc}
\hline Characteristics & & Number & $\%$ \\
\hline Respondent's organisation & 1. Client & 50 & 45.0 \\
& 2. Consultant & 29 & 26.1 \\
& 3. Contractor & 32 & 28.9 \\
Respondent's location & 1. Northern Region & 20 & 18.0 \\
& 2. Central Region & 28 & 25.2 \\
& 3. Southern Region & 21 & 18.9 \\
& 4. Eastern Region & 21 & 18.9 \\
Respondent's construction & 5. East Malaysia & 21 & 18.9 \\
industry experience & 1. No experience & - & - \\
& 2. 1 to 9 years & 14 & 12.6 \\
Respondent's D-B public & 3. More than 10 years & 97 & 87.4 \\
project experience & 1. No experience & 46 & 41.4 \\
& 2. 1 to 5 projects & 43 & 38.8 \\
& 3. 6 to 10 projects & 13 & 11.7 \\
& 4. 11 to 15 projects & 4 & 3.6 \\
& 5. 16 to 20 projects & 4 & 3.6 \\
& 6. More than 20 projects & 1 & 0.9 \\
\hline
\end{tabular}

Table 4. Ranking of Drivers for Adopting D-B

\begin{tabular}{lcccccc}
\hline Code & \multicolumn{5}{c}{$\begin{array}{c}\text { All Respondents } \\
\text { (Clients, Consultants and Contractors) }\end{array}$} & $\begin{array}{c}\text { ANOVA } \\
\text { (Between Clients, } \\
\text { Consultants and } \\
\text { Contractors) }\end{array}$ \\
\cline { 2 - 5 } & Mean & SD & Normalisation & Rank & p-Valve & $0.277^{* * *}$ \\
\hline DBD_1 & 4.50 & 0.90 & $1.000^{*}$ & 1 & $0.000^{* * *}$ & $0.185^{* * *}$ \\
DBD_2 & 4.50 & 0.82 & $1.000^{*}$ & 2 & $0.000^{* * *}$ & $0.748^{* * *}$ \\
DBD_16 & 4.32 & 0.83 & $0.735^{*}$ & 3 & $0.000^{* * *}$ & $0.569^{* * *}$ \\
DBD_7 & 4.24 & 0.82 & $0.618^{*}$ & 4 & $0.000^{* * *}$ & $0.063^{* * *}$ \\
DBD_4 & 4.22 & 0.73 & $0.588^{*}$ & 5 & $0.000^{* * *}$ & $0.316^{* * *}$ \\
DBD_10 & 4.13 & 0.82 & 0.456 & 6 & $0.000^{* * *}$ & $0.308^{* * *}$ \\
DBD_13 & 4.12 & 0.81 & 0.441 & 7 & $0.000^{* * *}$ & $0.070^{* * * *}$ \\
DBD_3 & 4.11 & 0.80 & 0.426 & 8 & $0.000^{* * *}$ & $0.171^{* * *}$ \\
DBD_11 & 4.11 & 0.82 & 0.426 & 9 & $0.000^{* * *}$ & $0.092^{* * * *}$ \\
DBD_6 & 4.05 & 0.84 & 0.338 & 10 & $0.000^{* * *}$ & $0.330^{* * *}$ \\
DBD_8 & 4.03 & 0.84 & 0.309 & 11 & $0.000^{* * *}$ & $0.382^{* * *}$ \\
DBD_9 & 3.98 & 0.84 & 0.235 & 12 & $0.000^{* * *}$ & $0.136^{* * *}$ \\
DBD_14 & 3.95 & 0.91 & 0.191 & 13 & $0.000^{* * *}$ & $0.544^{* * *}$ \\
DBD_5 & 3.94 & 0.97 & 0.176 & 14 & $0.000^{* * *}$ & \\
\hline
\end{tabular}


Table 4. Continued

\begin{tabular}{|c|c|c|c|c|c|c|}
\hline \multirow{2}{*}{ Code } & \multicolumn{5}{|c|}{$\begin{array}{l}\text { All Respondents } \\
\text { (Clients, Consultants and Contractors) }\end{array}$} & \multirow{2}{*}{$\begin{array}{c}\text { ANOVA } \\
\text { (Between Clients, } \\
\text { Consultants and } \\
\text { Contractors) }\end{array}$} \\
\hline & Mean & SD & Normalisation & Rank & $p$-Value & \\
\hline DBD_15 & 3.83 & 0.95 & 0.015 & 15 & $0.000^{* *}$ & $0.937^{* * *}$ \\
\hline DBD_12 & 3.82 & 0.80 & 0.000 & 16 & $0.000^{* *}$ & $0.724^{* * * *}$ \\
\hline
\end{tabular}

Notes: $\mathrm{SD}=$ Standard deviation; $\mathrm{NV}=$ Normalised value

"The normalised value indicates that the DBD is critical (normalised $\geq 0.50$ ).

"The one sample $t$-test result is significant at the 0.05 significance level ( $p$-value $<0.05)$.

"..The ANOVA result is insignificant at the 0.05 significance level (sig. $>0.05$ ).

\section{Maximise the use of resources between project team members and sharing of expertise (design and technical) with project team members}

Unexpectedly, the (DBD_1) "Maximise the use of resources between project team members" and (DBD_2) "Sharing expertise (design and technical) with project team members" is ranked topmost having a similar high mean score of 4.50 . The highestranking of these DBDs is unexpected since maximising the use of resources and sharing of expertise (design and technical) between project team members are ranked lower and is considered as an insignificant driver for the adoption of D-B in previous studies by (Darko, Zhang and Chan, 2017; Chan, Darko, and Ameyaw, 2017). On the other hand, these results agree with Chan et al. (2010) who reported that maximise the use of resources between the project team members, able to secure a reasonable and competitive price for public projects' and enabling exchange design and technical inputs from external consultants and builders may improve the quality of the design is equally important.

Notwithstanding, the finding also implies that Malaysian construction industry practitioners believe that adopting D-B can serve as an empirical benchmarking innovation, as a focused practice for motivating stakeholders to work as a single organisation in future construction projects. It is, in fact, preferable that the sharing of resources and expertise will keep variations to a minimum in construction projects to avoid time delays and cost increases (Ozorhon and Karahan, 2016). Therefore, when stakeholders acquire an objective to adopt the D-B procurement method into their development projects, the desire to set the pace for other project team members to follow can significantly help to drive these organisations to adopt D-B. Likewise, stakeholders and policymakers within the current construction industry would strive to work towards achieving the ultimate objective of fast-tracking construction projects realised through the adoption of D-B.

\section{Well-organised project team structure}

Interestingly, the DBD, (DBD_16) "Well-organised project team structure" is ranked third (mean $=4.32$ ). As an innovative procurement practice, the adoption of D-B in Malaysia has been overwhelmingly driven by effective project team structures associated with the concept of the fast track project delivery method in construction. This is an unsurprising finding since Malaysia has been faced with project delays in public projects not able to be completed within the scheduled time allocated with 
the worst effect attributed to poor project management techniques adopted by the project team (Ibrahim, Daniel and Ahmad, 2014). As such, this creates a sense of urgency for stakeholders to seek ways to improve the efficiency of managing projects in Malaysia. Therefore, the necessity and importance of well-organised and structured project teams for D-B adoption in the Malaysian construction industry are paramount.

However, there are a few influential factors, in particular, productivity and organisation-related factors that have created significant challenges towards the development and growth of the construction industry in Malaysia (Hamzah et al., 2011 ; Imtiaz and Ibrahim, 2005). As such, a well-organised project team structure could play a vital part in managing projects successfully. For example, adopting D-B able to deal with projects which are complex need to be supported by effective project delivery methods that attend to these complex needs and team structure requirements. This finding agrees with the findings of studies conducted by Mao et al. (2015) and Bagaya and Song (2016) where a well-organised project team structure is identified as one of the major drivers needed to implement D-B in construction practices. This finding has also been reinforced by Imtiaz and Ibrahim (2005) and Sekar, Viswanathan and Sambasivan, (2018) in that, some projects are not only measured in emphasising "cost", "time" and "quality" effectiveness but more so regarding the overall effect on having a good project team structure.

\section{High success rate}

The DBD, (DBD_7) "High success rate" is ranked fourth (mean $=4.24)$. The concept behind project success is established by the criteria and standards by which project managers' complete projects with the most favourable outcomes (Chan et al., 2010). Many of the reasons are also related to the involvement of the project parties such as the design consultant and builders who are involved early in the design stage of the project for the design to be buildable. Hence, in this study, most of the practitioners with more than 10 years' construction industry experience, agreed with the outcome of D-B having a higher project success rate compared to other project delivery methods. Therefore, when project clients have proof of project success, the desire to establish the route for other professionals to follow will drive them to adopt D-B (Hwang et al., 2017). This could explain why a high success rate in the construction project is ranked fourth in adopting D-B in the Malaysian setting.

\section{Dispute prevention during the construction stage}

The DBD, (DBD_4) "Dispute prevention during the construction stage", is ranked fifth (mean $=4.22$ ). The adoption of $D-B$ contributes to reducing many of the disputes and misconceptions during the construction stage. A similar situation is identified by Wall (1993) in Hong Kong, in undertaking a comprehensive review concerning construction disputes and identifying the relationship between D-B procurement selection with inherent risk allocation. With D-B, maintaining a cooperative environment becomes less complicated in comparison to traditional procurement methods in which conflicts are inherent in construction projects (Durdyev and Hosseini, 2020). Moreover, where conflicts result in adversarial stances and mistrust, they have a detrimental effect on project performance (Hamzah et al., 2011). 
This, DBD particular can be used to eliminate conflicts that appear to be daunting (Cheung, Wong and Lam, 2012). As such, efforts are directed towards reducing their magnitude and keeping the project parties under control (Vaaland, 2014). This benefit can be well received by Malaysian construction stakeholders and thus can significantly drive them to take relevant actions to adopt D-B.

Therefore, in light of the above discussion, it can be summarised based on the perceptions and views of various practitioners that although the adoption and development of D-B in Malaysia are still at the preliminary stage, the recognised benefits of D-B adoption have been recognised, encouraging some construction industry practitioners and stakeholders to embrace D-B. The public and private sectors should also formulate and implement sound strategies to educate and increase the public's knowledge and awareness of these benefits to promote more widespread adoption of D-B. One suggestion would be to create awareness through the media (e.g., print media, digital marketing, radio and television) on construction programs in Malaysia.

\section{Underlying Drivers for Adopting D-B in Malaysia}

The results of the factor analysis after the varimax rotation are displayed in Table 5. The eigenvalue, which measures the contributions of a variable to the principal components, is used as the criterion to determine the relevance of a variable. Judging from the previous study by Chan, Darko and Ameyaw (2017), only variables with eigenvalues greater than one should be retained. However, there are five items: DBD_1, DBD_2, DBD_3, DBD_12 and DBD_13, which are deleted given low loading items below 0.50. Normally, factor loadings higher than 0.50 are regarded as significant and contribute to the interpretation of the components. As shown in Table 5, only 11 DBDs are successfully loaded into three underlying components. The 11 significant DBDs are split into three principal components that could be named: (1) company-related forces, (2) cost-related forces and (3) industry-related forces. With these three components, $56.691 \%$ of the variance is accounted for by the DBDs (as shown in Table 5).

\section{Component 1: Company-Related Forces}

Component 1 consists of five underlying drivers: (1) "Interest in the designbuild approach", (2) "Well-organised project team structure", (3) "Dispute prevention during the construction stage", (4) "Reduction in work variations" and (5) "Improvement in tendering procedures". All these drivers are closely related to a client, consultant and contractor organisations in motivating people in the industry to adopt D-B. Therefore, this component is named "company-related forces". The total variance accounted for by this component is $34.076 \%$.

This factor summarises the effects of the working relationships among the project parties and is represented by the harmonious working relationships among the project team members and the cohesiveness of the D-B team. For instance, as the project leader in a D-B project, the confidence level of the construction team leader and the delegation of decision-making authority from the construction team leader may also affect the working environment of the project team (Chan, Cham and $\mathrm{Ma}, 2014)$. Likewise, high interest for D-B projects, a well-organised team and proper contract management will enhance harmonious working relationships 
among project parties, which can allow a clear flow of communication on matters of time, cost and quality (Hidenori, 1995). Low disputes and a well-integrated project team showed its criticality to the project's success (Sanvido et al., 1992). Previous studies have revealed that a good project team structure encourages project participants to work together cohesively for a cost-effective design through an optimum balance of design, build-ability and cost (Murray and Seif, 2013). In the tendering process, the contractor may also be attracted to the unique nature of the D-B project so that each tenderer can submit a distinctive proposal based entirely on the expertise of the D-B team. Hence, D-B projects have shown that company-related variables affect the adoption level of D-B projects (Ling and Liu, 2014).

Table 5. Results of the Factor Analysis

\begin{tabular}{|c|c|c|c|c|c|}
\hline \multicolumn{2}{|l|}{ Item } & $\begin{array}{l}\text { Factor } \\
\text { Loading }\end{array}$ & $\begin{array}{c}\text { Initial } \\
\text { Eigenvalue }\end{array}$ & $\begin{array}{c}\text { Percentage } \\
\text { of Variance } \\
\text { Explained }\end{array}$ & $\begin{array}{l}\text { Cumulative } \\
\text { Percentage } \\
\text { of Variance }\end{array}$ \\
\hline \multicolumn{2}{|c|}{$\begin{array}{l}\text { Component 1: Company-Related } \\
\text { Forces }\end{array}$} & & 3.748 & 21.295 & 21.295 \\
\hline DBD_5 & $\begin{array}{l}\text { Interest in the design- } \\
\text { build approach }\end{array}$ & 0.827 & & & \\
\hline DBD_16 & $\begin{array}{l}\text { Well-organised project } \\
\text { team structure }\end{array}$ & 0.708 & & & \\
\hline DBD_4 & $\begin{array}{l}\text { Dispute prevention } \\
\text { during the construction } \\
\text { stage }\end{array}$ & 0.599 & & & \\
\hline DBD_8 & $\begin{array}{l}\text { Reduction in works } \\
\text { variations }\end{array}$ & 0.562 & & & \\
\hline DBD_9 & $\begin{array}{l}\text { Improvement in } \\
\text { tendering procedures }\end{array}$ & 0.555 & & & \\
\hline \multicolumn{2}{|c|}{ Component 2: Cost-Related Forces } & & 1.433 & 17.880 & 39.175 \\
\hline DBD_15 & $\begin{array}{l}\text { Capability to } \\
\text { provide clients with } \\
\text { a guaranteed fixed } \\
\text { schedule }\end{array}$ & 0.810 & & & \\
\hline DBD_11 & Better project pricing & 0.741 & & & \\
\hline DBD_14 & $\begin{array}{l}\text { Capability to } \\
\text { provide clients with a } \\
\text { guaranteed cost }\end{array}$ & 0.566 & & & \\
\hline \multicolumn{2}{|c|}{$\begin{array}{l}\text { Component 3: Industry-Related } \\
\text { Forces }\end{array}$} & & 1.054 & 17.516 & 56.691 \\
\hline DBD_6 & $\begin{array}{l}\text { Greater allocation of } \\
\text { risks to the contractors }\end{array}$ & 0.784 & & & \\
\hline DBD_7 & High success rate & 0.677 & & & \\
\hline DBD_10 & Better track record & 0.593 & & & \\
\hline
\end{tabular}




\section{Component 2: Cost-Related Forces}

Component 2 includes three drivers: (1) "Capability to provide the client with a guaranteed fixed schedule", (2) "Better project pricing" and (3) "Capability to provide the client with a guaranteed cost". These factors emphasise strategies in meeting the project's cost budget and schedule, which are inter-related for managing a project, termed "cost-related forces". The total variance accounted for by this component is $13.029 \%$.

This factor describes the emphasis of the project's client objectives, specifically regarding time and cost. Since the factor loading of sharing the resources, design, expertise and sole responsibility on the contractor organisation is relatively lower than the factor loadings of the other factor variables, this factor is highly related to the fixed schedule and cost-related factors to inspire or encourage the project team to adopt D-B. If a D-B project is prestigious and with high value to the contractor, the contractor naturally will position extra effort to accomplish the project on time and budget. D-B makes the best use of new inputs by the project's parties early at the pre-planning stage, thus saving much time since the buildability of the project is improved (Hashim et al., 2015; Lamont, 2016). Furthermore, D-B allows project parties to optimise the design and methods of construction with cost benefits. Hence, the performance of the D-B project can be improved (Xia and Chan, 2010). Lastly, D-B allows a complex project to be implemented more cost-effectively within a shorter period by minimising the complexity of the project by being awarded to the right contractor (Blake, Browne and Sime, 2016).

\section{Component 3: Industry-Related Forces}

Component 3 comprises three drivers: (1) "Greater allocation of risks to the contractors", (2) "High success rate" and (3) "Better track record", which accounts for $9.586 \%$ of the variance. These three drivers can be achieved through the competency of all parties, such as the client, consultant and contractor (Chan, Darko and Ameyaw, 2017). Therefore, Component 3 is named "Industry-related forces".

The results also indicate that one of the potential drivers that motivate the project's parties to adopt D-B is due to the successful track record and allocation of risks. These drivers relate to the construction industry's perspectives on the D-B method in general (Chan, Chan and Ma, 2014). Regarding an improved track record, such an arrangement can be achieved through the use of partnering, which encourages mutual trust amongst the project's parties (Bo and Chan, 2012). Thus, it enables the project's parties to proceed with the D-B procurement method in delivering a successful project. Furthermore, the effectiveness of the construction team leader includes their technical and project management skills, experience and capabilities, commitment and adaptability along with support from the parent company of the construction team leader as a value enhancement exercise for the broader adoption of D-B in providing the best value-for-money option for the project (Hidenori, 1995 ). The adoption of value management can consequently lead to a better success rate without adversely affecting the quality and performance of the project (Bo and Chan, 2012). In transferring risks to a single entity (i.e., the contractor's team), it enhances the selection decision to adopt D-B by the project client (Chakra and Ashi, 2019). Hence, with the high collaboration of all parties associated with the project, well-defined scope and shared understanding of the 
scope will have a significant positive impact on the success of the D-B project (Chakra and Ashi, 2019). Further, it will enhance the level of D-B adoption in the construction industry.

\section{Comparison with Some Selected Countries}

This section aims to consolidate the findings and present an overview of the major drivers for adopting $D-B$ in the global construction industry. This study focuses on nations in the Association of Southeast Asian Nations (ASEAN), including Vietnam, Singapore, Indonesia and Malaysia, because these countries tend to have similar political, economic, social and environmental conditions. While these studies may have different purposes or aims, the studies do illustrate the relevant DBDs. From the comparison, the main drivers for adopting D-B from prior studies can be categorised using this study's three underlying drivers (as shown in Table 6). In other words, this finding suggests that the motivations for accepting or rejecting D-B in other countries are relevant to the Malaysian construction industry. Therefore, researchers, policymakers and industry professionals should target these drivers in moving Malaysia's construction industry towards a knowledge-based and highincome sector.

Table 6. Drivers for Adopting D-B in Selected Countries

\begin{tabular}{|c|c|c|c|c|}
\hline Country & Sources & $\begin{array}{l}\text { Component 1: } \\
\text { Company- } \\
\text { Related Forces }\end{array}$ & $\begin{array}{l}\text { Component 2: } \\
\text { Cost-Related } \\
\text { Forces }\end{array}$ & $\begin{array}{c}\text { Component 3: } \\
\text { Industry-Related } \\
\text { Forces }\end{array}$ \\
\hline Malaysia & $\begin{array}{l}\text { Jaafar and Nuruddin } \\
\text { (2012) }\end{array}$ & $\sqrt{ }$ & $\sqrt{ }$ & - \\
\hline Malaysia & $\begin{array}{l}\text { Gomez and Gambo } \\
(2016)\end{array}$ & $\sqrt{ }$ & - & - \\
\hline Malaysia & Saaidin et al. (2016) & - & - & $\sqrt{ }$ \\
\hline Singapore & $\begin{array}{l}\text { Ling and Gunawansa } \\
\text { (2011) }\end{array}$ & - & - & $\sqrt{ }$ \\
\hline Singapore & Ofori (2018) & $\sqrt{ }$ & - & - \\
\hline Singapore & Ke et al. (2019) & - & $\sqrt{ }$ & - \\
\hline Indonesia & Marzuki et al. (2019) & $\sqrt{ }$ & - & - \\
\hline \multirow[t]{2}{*}{ Vietnam } & $\begin{array}{l}\text { Le-Hoai, Lee and } \\
\text { Nguyen (2013) }\end{array}$ & $\sqrt{ }$ & $\sqrt{ }$ & - \\
\hline & Frequency & 5 & 3 & 2 \\
\hline
\end{tabular}

Prior studies are exploring the performance and rapid development of Malaysia's construction industry, focusing on the need to conduct further research on construction procurement methods, including D-B. Specifically, from investigating the relationship between the different economic phases and the development of the procurement methods in Malaysia, one study has identified several factors that can impact decisions in accepting or rejecting the adoption of D-B, including having a stable client financial capability, adequate cash flow 
by the D-B contractor, high interest of construction management and design knowledge, good teamwork and systematic tendering process to overcome the complexity of the project, i.e., the company- and cost-related forces (Jaafar and Nuruddin, 2012). Also, the key findings of another study revealed that the effectiveness in presenting D-B's economic advantages to clients significantly affects the selection of the procurement approach in Malaysia, i.e., cost-related forces (Gomez and Gambo, 2016). Lastly, another study suggests that some Malaysian construction projects are implementing the traditional procurement methods due to a lack of awareness of D-B's benefits, i.e., industry-related forces (Saaidin et al., 2016). In other words, prior studies have already identified all of the three underlying drives. However, those findings are identified in separate studies. This study, in one single study, confirms that all of those three underlying drivers play a role in enhancing the adoption of D-B in Malaysia's construction industry. Therefore, to increase the effectiveness and efficiencies of policies that target the enhancement of D-B adoption in practice, industry practitioners should target all of those drivers as a whole.

In the neighbouring state of Singapore, while consultants such as architects and engineers formerly disbelieve that $D$-B projects have better quality, time and cost performance compared to traditional D-B-B projects, clients are opting to adopt D-B following the success of the D-B scheme for the Housing and Development Board program launched in constructing flats in 2005 (Ling and Gunawansa, 2011). Another study also suggests that the high success rate associated with D-B projects results in a favourable view among clients (Ke et al., 2019). On the other hand, as D-B provides a leadership position that entails many responsibilities including both the design and construction elements of a project to contractors, contractors are taking full advantage of this opportunity to exercise their management capabilities and push the construction industry to achieve better performance (Ling and Gunawansa, 2011). Lastly, the culture of the construction industry in Singapore reveals that the main driving force for $D-B$ adoption is in helping managers to communicate and motivate their coworkers, enabling clients to offer incentives for innovations, offering an alternative approach for transferring tendering procedures to local construction firms and helping project managers to integrate project participants effectively (Ofori, 2018). In the context of Indonesia, better clarification among construction project parties that prevents construction disputes during the construction stage is seen as the main driver in adopting the D-B system (Marzuki et al., 2019). In Vietnam, projects are avoiding D-B due to the numerous difficulties encountered during the initial implementation process of the D-B procurement method that results from unfamiliarity and inexperience with the approach (Le-Hoai, Lee and Nguyen, 2013).

In conclusion, prior studies have identified the company- and cost-related driving forces that affect the adoption of $D-B$ in the global construction industry. However, these studies might overlook the industry-related forces which involve having a higher allocation of risks to contractors, a higher success rate and a better track record (Moza and Paul, 2018). Conversely, this study demonstrates that all three forces are playing a significant role in enhancing the adoption of $D-B$ in the construction industry. Therefore, similarly to Malaysia, nations should disseminate information that $D$-B is the appropriate choice if project stakeholders are motivated to enhance the construction industry's performance. 


\section{CONCLUSION}

Understanding the drivers for adopting design-build in practice can assist developing nations to promote the broader adoption of D-B in the construction industry. Therefore, this study identifies key drivers that are affecting D-B adoption for public sector projects in a developing country by analysing the collected questionnaire survey data with 111 industry professionals in Malaysia. The major findings include:

1. All the identified DBDs in this study (16 in total) are essential for adopting D-B in public construction projects.

2. There are no significant differences found between the mean of different geographical construction areas/regions and different project parties, (i.e., project client, consultant and contractor).

3. From the 16 DBDs, the most important or key DBDs are "Maximise the use of resources between project team members", "Sharing of expertise (design and technical) with project team members", "Well-organised project team structure", "High success rate" and "Dispute prevention during the construction stage".

4. From the 16 DBDs, 11 DBDs are successfully grouped into three underlying components, i.e., "company-related forces", "cost-related forces" and "industry-related forces".

In a nutshell, this study contributes to the existing body of knowledge is in capturing the key DBDs and providing an in-depth understanding of the underlying components for adopting D-B. Researchers and industry practitioners can use these findings to enhance the level of D-B adoption in developing countries by allowing the construction industry to focus on the key DBDs and its underlying components. Paying particular attention to those items can help formulate and implement the right strategies in stimulating and attracting more significant interest in the adoption of D-B. Also, industry practitioners can use these findings to make better-informed decisions regarding whether to adopt D-B in their projects. Making informed decisions can improve the efficiency and effectiveness of their efforts in selecting a suitable procurement method from focusing upon the significant DBDs with high importance.

Also, industry practitioners, particularly consultants and contractors, should be encouraged to motivate their respective teams to adopt D-B based on the main drivers before deciding a suitable procurement method for their project. specifically, the ability to maximise resources by the contractor and sharing expertise by the consultant are equally crucial for the entire project team to work together and prevent any disputes from occurring among the parties leading to the successful completion of the project.

In conclusion, this study is one of only a few empirical studies to present the underlying drivers for adopting $D-B$ in developing nations. Therefore, while the theoretical contribution of this research is the analysis of the key DBDs that influence the adoption of D-B in Malaysia, the findings and implications of this study could be useful to policymakers, key project parties and industry practitioners in other 
developing countries. In other words, the findings of this study make a significant contribution to D-B in the public sector construction literature in presenting the major forces driving D-B adoption in a developing country.

\section{ACKNOWLEDGEMENTS}

This work was supported by Universiti Malaysia Pahang research grant [RDU190340]. Also, the authors wish to acknowledge the assistance and encouragement from the Malaysian construction industry professionals and experienced D-B contractors who provided their insight and expertise, which greatly improved this research.

\section{REFERENCES}

Akintoye A. (2014). Design and build: A survey of construction contractors' views. Construction Management and Economics, 12(2): 155-163. https://doi. org/10.1080/01446199400000021.

Aljohani, A. (2017). Construction projects cost overrun: What does the literature tell us? International Journal of Innovation, Management and Technology, 8(2): 137-143. https://doi.org/10.18178/ijimt.2017.8.2.717.

Ando, M. (2016). History of the past 30 years' transition and present status of project delivery methods and contracting system in Japan. Paper presented at the 1st International Conference of Construction Project Delivery Methods and Quality Ensuring System Symposium.

. (2011). Japanese "design and build": Risk-taking and competence acquisition in the social aspect of design and build; Order and contract. Journal of Architecture and Building Science, Architectural Institute of Japan, 3: 18-21.

Bagaya, O. and Song, J. (2016). Empirical study of factors influencing schedule delays of public construction projects in Burkina Faso. Journal of Management in Engineering, 32(5): 05016014. https://doi.org/10.1061/ (ASCE)ME.1943-5479.0000443.

Behr, D. (2017). Assessing the use of back translation: The shortcomings of back translation as a quality testing method. International Journal of Social Research Methodology, 20(6): 573-584. https://doi.org/10.1080/13645579.20 16.1252188.

Blake, S.H., Browne, J. and Sime, S. (2016). A Practical Approach to Alternative Dispute Resolution. Oxford: Oxford University Press. Available at: https://books.google.com/books?hl=en\&lr=\&id=31 pnDAAAQBAJ\&oi $=$ fnd \&pg $=P P 1 \& d q=$ related: $94 \mathrm{mGm6zqL} A \mathrm{AJ}:$ scholar.google.com $/ \&$ ots =AOu81CcnjE\&sig=16ndNjAvif5tMV87exJOTSnozaU [Accessed on 27 August 2019].

Bo, X. and Chan, A.P. (2012). Investigation of barriers to entry into the designbuild market in the People's Republic of China. Journal of Construction Engineering and Management, 138(1): 120-127. https://doi.org/10.1061/ (ASCE)CO.1943-7862.0000387. 
Bogus, S.M., Migliaccio, G.C. and Jin, R. (2013). Study of the relationship between procurement duration and project performance in design-build projects: Comparison between water/wastewater and transportation sectors. Journal of Management in Engineering, 29(4): 382-391. https://doi.org/10.1061/ (ASCE)ME.1943-5479.0000165.

Braimah, N. (2014). Understanding construction delay analysis and the role of preconstruction programming. Journal of Management in Engineering, 30(5): 04014023. https://doi.org/10.1061/(ASCE)ME.1943-5479.0000216.

Campos, G.O., Zimek, A., Sander, J., Campello, R.J., Micenková, B., Schubert, E. and Houle, M.E. (2016). On the evaluation of unsupervised outlier detection: Measures, datasets and an empirical study. Data Mining and Knowledge Discovery, 30(4): 891-927. https://doi.org/10.1007/s10618-015-0444-8.

Chakra, H.A. and Ashi, A. (2019). Comparative analysis of design/build and design/bid/build project delivery systems in Lebanon. Journal of Industrial Engineering International, 15(1): 147-152. https://doi.org/10.1007/s40092-019 $-00323-1$.

Chan, A.P., Javed, A.A., Lyu, S., Hon, C.K. and Wong, F.K. (2016). Strategies for improving safety and health of ethnic minority construction workers. Journal of Construction Engineering and Management, 142(9): 05016007. https://doi.org/10.1061/(ASCE)CO.1943-7862.0001148.

Chan, A.P.C., Darko, A. and Ameyaw, E.E. (2017). Strategies for promoting green building technologies adoption in the construction industry: An international study. Sustainability, 9(6): 969. https://doi.org/10.3390/su9060969.

Chan, D.W., Lam, P.T., Chan, A.P. and Wong, J.M. (2010). Achieving better performance through target cost contracts: The tale of an underground railway station modification project. Facilities, 28(5-6): 261-277. https://doi .org/10.1108/02632771011031501.

Chan, D.W.M., Chan, J.H.L. and Ma, T. (2014). Developing a fuzzy risk assessment model for guaranteed maximum price and target cost contracts in South Australia. Facilities, 32(11/12): 624-646. https://doi.org/10.1108/F-08-2012 $-0063$.

Chatterjee, D. (2012). Innovativeness: A team knowledge and communication perspective. International Journal of Innovation and Learning, 12(3): 229-246. https://doi.org/10.1504/IJIL.2012.048807.

Chen, W.T. and Chen, T.T. (2007). Critical success factors for construction partnering in Taiwan. International Journal of Project Management, 25(5): 475-484. https://doi.org/10.1016/j.ijproman.2006.12.003.

Chen, W.T., Chen, T.T., Lu, C.S. and Liu, S.S. (2012). Analyzing relationships among success variables of construction partnering using structural equation modeling: A case study of Taiwan's construction industry. Journal of Civil Engineering and Management, 18(6): 783-794. https://doi.org/10.3846/1392 3730.2012 .735062$.

Cheung, S.O., Wong, P.S. and Lam, A.L. (2012). An investigation of the relationship between organizational culture and the performance of construction organizations. Journal of Business Economics and Management, 13(4): 688704. https://doi.org/10.3846/16111699.2011.620157.

Choudhry, R.M., Gabriel, H.F., Khan, M.K. and Azhar, S. (2017). Causes of discrepancies between design and construction in the Pakistan construction industry. Journal of Construction in Developing Countries, 22(2): 1-18. https://doi.org/10.21315/jcdc2017.22.2.1. 
Darko, A., Chan, A.P., Owusu-Manu, D.G. and Ameyaw, E.E. (2017a). Drivers for implementing green building technologies: An international survey of experts. Journal of Cleaner Production, 145: 386-394. https://doi.org/10.1016/j. jclepro.2017.01.043.

Darko, A., Chan, A.P.C., Gyamfi, S., Olanipekun, A.O., He, B.J. and Yu, Y. (2017b). Driving forces for green building technologies adoption in the construction industry: Ghanaian perspective. Building and Environment, 125: 206-215. https://doi.org/10.1016/j.buildenv.2017.08.053.

Darko, A., Zhang, C. and Chan, A.P. (2017). Drivers for green building: A review of empirical studies. Habitat International, 60: 34-49. https://doi.org/10.1016/j. habitatint.2016.12.007.

Dawes, J. (2008). Do data characteristics change according to the number of scale points used? An experiment using 5-point, 7-point and 10-point scales. International Journal of Market Research, 50(1): 61-77. https://doi. org/10.1177/147078530805000106.

DBIA (Design Build Institute of America) (2018). 2018 State Statute Report, DBIA 9/4/2018. Washington DC: DBIA.

Demirkesen, S. and Ozorhon, B. (2017). Impact of integration management on construction project management performance. International Journal of Project Management, 35(8): 1639-1654. https://doi.org/10.1016/j.ijproman .2017.09.008.

Denti, L. and Hemlin, S. (2012). Leadership and innovation in organizations: A systematic review of factors that mediate or moderate the relationship. International Journal of Advanced Construction Management, 16(3): 13-18. https://doi.org/10.1142/S1363919612400075.

Durdyev, S. and Hosseini, M. (2020). Causes of delays on construction projects: A comprehensive list. International Journal of Managing Projects in Business, 13(1): 20-46. https://doi.org/10.1108/IJMPB-09-2018-0178.

El-Karim, M.S.B.A.A., El Nawawy, O.A.M. and Abdel-Alim, A.M. (2017). Identification and assessment of risk factors affecting construction projects. HBRC Journal, 13(2): 202-216. https://doi.org/10.1016/j.hbrcj.2015.05.001.

Eriksson, P.E. (2017). Procurement strategies for enhancing exploration and exploitation in construction projects. Journal of Financial Management of Property and Construction, 22(2): 211-230. https://doi.org/10.1108/ JFMPC-05-2016-0018.

Gibb, A.G.F. and Isack, F. (2003). Re-engineering through pre-assembly: Client expectations and drivers. Building Research and Information, 31 (2): 146-160. https://doi.org/10.1080/09613210302000.

Gogol, B., Brunner, M., Goetz, T., Martin, R., Ugen, S., Keller, U., Fischbach, A. and Preckel, F. (2014). "My questionnaire is too long!" The assessments of motivational-affective constructs with three-item and single-item measures. Contemporary Educational Psychology, 39(3): 188-205. https://doi.org/ 10.1016/j.cedpsych.2014.04.002.

Goldstein, M. and Uchida, S. (2016). A comparative evaluation of unsupervised anomaly detection algorithms for multivariate data. PLOS ONE, 11(4): e0152173. https://doi.org/10.1371/journal.pone.0152173.

Gomez, C. and Gambo, M. (2016). Evaluation of special purpose vehicle organisation skill sets taxonomy for effective public-private partnership infrastructure project delivery. Journal of Construction in Developing Countries, 21 (1): 147-165. http://dx.doi.org/10.21315/jcdc2016.21.1.8. 
Gudienè, N., Banaitis, A., Banaitienè, N. and Lopes, L. (2013). Development of a conceptual critical success factors model for construction projects: A case of Lithuania. Procedia Engineering, 57: 392-397. https://doi.org/10.1016/j. proeng.2013.04.051.

Hair, J.F., Money, A.H., Samovel, P. and Page, M. (2007). Research methods for business. Education + Training, 49(4): 336-337. https://doi.org/10.1108/et .2007.49.4.336.2.

Halil, F.M., Nasir, N.M., Shukur, A.S. and Hashim, H. (2018). A quantitative analysis study on the implementation of partnering in the design and build construction project. IOP Conference Series: Earth and Environmental Science, 117: 012033. https://doi.org/10.1088/1755-1315/117/1/012033.

Hamzah, N., Khoiry, M.A., Arshad, I., Tawil, N.M. and Ani, A.C. (2011). Cause of construction delay: Theoretical framework. Procedia Engineering, 20: 490495. https://doi.org/10.1016/j.proeng.2011.11.192.

Hashim, A.E., Samikon, S.A., Ismail, F. and Ismail, Z. (2015). Managing facilities on Malaysian low-cost public residential for sustainable adaptation. Procedia - Social and Behavioral Sciences, 168: 52-60. https://doi.org/10.1016/ j.sbspro.2014.10.209.

Hassanien, A. and Dale, C. (2012). A framework for distributed key management schemes in public construction projects in the United States. Paper presented at the 25th ASCE International Performance Engineering and Construction Management Conference 2012. Arizona, USA.

Hemlin, C. (1994). Team building a global team at Apple Computer. Employment Relations Today, 21 (1): 55-62. https://doi.org/10.1002/ert.3910210107.

Hidenori, K. (1995). Trust, integration and leadership: Tenets of Japanese design and build. Paper presented at the Design and Build Projects: International Experiences International Congress on Construction. Singapore, 5-6 October.

Hugick, L. and Best, J. (2008). Questionnaire length. In P.J. Lavrakas (ed.), Encyclopedia of Survey Research Methods. Thousand Oaks, CA: SAGE Publications, Inc. Available at: https://books.google.com/books?hl=en $\& \mid r=\& i d=R h p 1 A w A A Q B A J \& O i=f n d \& p g=P P 1 \& d q=L a v r a k a s .+(2013)$ .+Questionnaire+Length.+In+Encyclopedia+of+Survey+Research+Methods .\&ots=NTO2BXqJya\&sig=5xFsWQX87YglLZtpVdj61Y6iSOo [Accessed on 27 June 2019].

Hwang, B.G. and Lim, E.S.J. (2013). Critical success factors for key project players and objectives: Case study of Singapore. Journal of Construction Engineering and Management, 139(2): 204-215. https://doi.org/10.1061/(ASCE)CO.19437862.0000597

Hwang, B.G., Zhao, X., See, Y.L. and Zhong, Y. (2015). Addressing risks in green retrofit projects: The case of Singapore. Project Management Journal, 46(4): 76-89. https://doi.org/10.1002/pmj.21512.

Hwang, Y.S., Bartlett, B., Greben, M. and Hand, K. (2017). A systematic review of mindfulness interventions for in-service teachers: A tool to enhance teacher wellbeing and performance. Teaching and Teacher Education, 64: 26-42. https://doi.org/10.1016/j.tate.2017.01.015.

Ibrahim, I.I., Daniel, S. and Ahmad, A. (2014). Investigating Nigerian indigenous contractors' project planning in construction procurement: An explanatory approach. International Journal of Civil and Environmental Engineering, IJCEE-IJENS, 14(4): 16-25. 
Imtiaz, G. and Ibrahim, A.R. (2005). Lean production system in project delivery: The way forward for Malaysian construction industry. Paper presented at the Kuala Lumpur Quantity Surveyor International Convention (QSIC). Kuala Lumpur.

Jaafar, M. and Nuruddin, A.R. (2012). The development of public and private construction procurement systems in the Malaysian construction industry. Journal of Design and Built Environment, 11(1): 1-11.

Kaiser, H. (1970). A second generation. Little Jiffy Psychometrika, 35: 401-415. https://doi.org/10.1007/BF02291817.

Ke, Y., Ling, F. Y., Ning, Y. and Zhang, Z. (2019). Managing relationships in large public projects: Comparative study of China and Singapore. Built Environment Project and Asset Management, 9(3): 348-363. https://doi.org/10.1108/ BEPAM-10-2018-0128.

Kerzner, H. (2014). Strategic planning for a project office. Project Management Journal, 34(2): 13-25. https://doi.org/10.1177/875697280303400203.

Khairuddin, A.R. (2016). Appraising policies on joint ventures for construction work in Malaysia. In K. Kobayashi, A.R. Khairuddin, G. Ofori and S. Ogunlana (eds.), Joint Ventures in Construction. London: Thomas Telford Publishing, 150-160.

Khairulzan, Y. and Nabilah, A.H.S. (2015). The significant factors causing delay of building construction projects in Malaysia. Malaysia Construction Journal, 20: 593-599.

Khalfan, M.M., Oyegoke, A.S., McDermott, P. and Dickinson, M. (2014). Managing risk and uncertainty in an agile construction environment: Application of agile building specialist model. International Journal of Agile Systems and Management, 3(3-4): 248-262.

Khan, M.A. (2014). Accelerated Bridge Construction: Best Practices and Techniques. Oxford: Elsevier.

Khan, R.A., Liew, M.S. and Ghazali, Z. (2014). Malaysian construction sector and Malaysia Vision 2020: Developed nation status. Procedia - Social and Behavioral Sciences, 109: 507-513. https://doi.org/10.1016/j.sbspro.2013 .12 .498 .

Khoshgoftar, M., Bakar, A.H.A. and Osman, O. (2010). Causes of delays in Iranian construction projects. International Journal of Construction Management, 10(2): 53-69. https://doi.org/10.1080/15623599.2010.10773144.

Kinkel, S. and Som, O. (2010). Internal and external R\&D collaboration as drivers of the product innovativeness of the German mechanical engineering industry. International Journal of Product Development, 12(1): 6-20. https://doi.org/10.1504/IJPD.2010.034310.

Labaw, P.J. (1980). Advanced Questionnaire Design. Cambridge, MA: Abe Books. Available at: https://www.abebooks.com/Advanced-Questionnaire-DesignLabaw-Patricia-J/1786142332/bd [Accessed on 27 June 2019].

Lam, E.W.M., Chan, A.P.C. and Chan, D.W.M. (2008). Determinants of successful design-build projects. Journal of Construction Engineering and Management, 134(5): 333-341.

. (2006). Barriers to applying the design-build procurement method in Hong Kong. Architectural Science Review, 49(2): 189-195. https://doi.org/10.3763/ asre.2006.4926.

Lam, P.T.I. and Wong, F.W.H. (2009). Improving building project performance: How buildability benchmarking can help. Construction Management and Economics, 27(1): 41-52. https://doi.org/10.1080/01446190802570498. 
Lamont, P.J. (2016). Construction executive: Options for successful dispute resolution. Available at: https://enewsletters.constructionexec.com/ riskmanagement/2016/06/options.

Lee, Z.P., Rahman, R.A. and Doh, S.I. (2020). Success factors of design-build public sector projects in Malaysia. IOP Conference Series: Materials Science and Engineering, 712: 012045. https://doi.org/10.1088/1757-899X/712/1/012045.

Le-Hoai, L., Lee, Y.D. and Lee, J.Y. (2008). Delay and cost overruns in Vietnam large construction projects: A comparison with other selected countries. KSCE Journal of Civil Engineering, 12(6): 367-377. https://doi.org/10.1007/ S12205-008-0367-7.

Le-Hoai, L., Lee, Y.D. and Nguyen, A.T. (2013). Estimating time performance for building construction projects in Vietnam. KSCE Journal of Civil Engineering, 17: 1-8. https://doi.org/10.1007/s12205-013-0862-3.

Levin, P. (ed.) (2016). Construction Contract Claims, Changes and Dispute. 3rd Ed. Reston, VA: American Society of Civil Engineers (ASCE). https://doi.org/ $10.1061 / 9780784414293$.

Li, Y., Yang, L., He, B. and Zhao, D. (2014). Green building in China: Needs great promotion. Sustainable Cities Society, 11: 1-6. https://doi.org/10.1016/j.scs .2013.10.002.

Ling, F.Y.Y. and Gunawansa, A. (2011). Strategies for potential owners in Singapore to own environmentally sustainable homes. Engineering, Construction and Architectural Management, 18(6): 579-594. https://doi. org/10.1108/09699981111180890.

Ling, F.Y.Y. and Kerh, S.H. (2004). Comparing the performance of design-build and design-bid-build building projects in Singapore. Architectural Science Review, 47(2): 163-175. https://doi.org/10.1080/00038628.2004.9697040.

Ling, F.Y.Y. and Leong, E.F.K. (2012). Performance of design-build projects in terms of cost, quality and time: Views of clients, architects and contractors in Singapore. Australian Journal of Construction Economics and Building, 2(1): 37-46. https://doi.org/10.5130/AJCEB.v2i1.2885.

Ling, F.Y.Y. and Liu, M. (2014). Using neural network to predict performance of design-build projects in Singapore. Building and Environment, 39(10): 12631274. https://doi.org/10.1016/j.buildenv.2004.02.008.

Mao, C., Shen, Q., Pan, W. and Ye, K. (2015). Major barriers to off-site construction: the developer's perspective in China. Journal of Management Engineering, 31 (3): 04014043 . https://doi.org/10.1061/(ASCE)ME.1943-5479.0000246.

Marzuki, P., Oktavianus, A., Regina, A., Hasiholan, B. and Meifrinaldi. (2019). Interface problems in change order-challenged projects. Journal of Construction in Developing Countries, 24(2): 1-22. https://doi.org/10.21315/ jcdc2019.24.2.1.

McLeod, S. (2019). Likert scale definition, examples and analysis. Simply Psychology, 3 August. Available at: https://www.simplypsychology.org/likert-scale.html [Accessed on 27 June 2019].

Melzack, R. (1987). The short-form McGill pain questionnaire. Pain, 30(2): 191-197. https://doi.org/10.1016/0304-3959(87)91074-8.

Merrow, E.W. (201 1). Industrial Megaprojects: Concepts, Strategies and Practices for Success. Hoboken, NJ: John Wiley \& Sons, Inc. 
Misangyi, V.F., LePine, J.A., Algina, J. and Goeddeke, J.F. (2006). The adequacy of repeated-measures regression for multilevel research: Comparisons with repeated-measures ANOVA, multivariate repeated-measures ANOVA and multilevel modeling across various multilevel research designs. Organizational Research Methods, 9(1): 5-28. https://doi.org/10.1177/ 1094428105283190.

Moore, D.R. and Dainty, A.R.J. (2001). Intra-team boundaries as inhibitors of performance improvement in UK design and build projects: A call for change. Construction Management and Economics, 19(6): 559-562. https://doi.org/10.1080/01446190110055508.

Moza, A. and Paul, V.K. (2018). Analysis of claims in public works construction contracts in India. Journal of Construction in Developing Countries, 23(2): 7-26. https://doi.org/10.21315/jcdc2018.23.2.2.

Murray, M. and Seif, M. (2013). Causes of project delays in Nigerian construction industry European. Journal of Civil Engineering and Architecture, 10(1): 1-7.

Nitithamyong, P. and Tan, Z. (2007). Determinants for effective performance of external project management consultants in Malaysia. Engineering, Construction and Architectural Management, 14(5): 463-478. https://doi .org/10.1108/09699980710780764.

Ofori, G. (2018). Construction in developing countries: Need for new concepts. Journal of Construction in Developing Countries, 23(2): 1-6. https://doi.org/ 10.21315/jcdc2018.23.2.1.

Osborne, J.W. (2015). What is rotating in exploratory factor analysis? Practical Assessment, Research and Evaluation, 20(1): 1-7. https://doi.org/10.7275/ $\mathrm{hb} 2 \mathrm{~g}-\mathrm{m0} 00$.

Osei-Kyei, R. and Chan, A.P.C. (2017). Developing a project success index for publicprivate partnership projects in developing countries. Journal Infrastructure System, 23(4): 04017028. https://doi.org/10.1061/(ASCE)IS.1943-555X.0000388.

Ott, R.L. and Longnecker, M. (2010). An Introduction to Statistical Methods and Data Analysis. Boston, MA: Cengage Learning. Available at: https://books

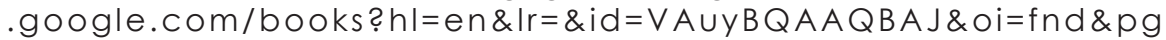
$=P P 1 \& o \dagger s=9$ eBPHqeVNp\&sig $=6$ Chg AV8DBpVnNxd_BHCqvJWa9hY [Accessed on 17 May 2019].

Ozorhon, B. and Karahan, U. (2016). Critical success factors of building information modeling implementation. Journal of Management in Engineering, 33(3): 04016054. https://doi.org/10.1061/(ASCE)ME.1943-5479.0000505.

Pacheco, R., Ordonez, J. and Martínez, G. (2012). Energy efficient design of building: A review. Renewable and Sustainable Energy Reviews, 16(6): 3559-3573. https://doi.org/10.1016/j.rser.2012.03.045.

Palaneeswaran, E. and Kumaraswamy, M.M. (2000). Contractor selection for design/build projects. Journal of Construction Engineering and Management, 126(5): 331-339. https://doi.org/10.1061/(ASCE)0733-9364(2000) 126:5(331).

Pallant, J. (2020). SPSS Survival Manual: A Step by Step Guide to Data Analysis Using IBM SPSS. New York: Routledge. Available at: https://books.google $. c o m / b o o k s ? h l=e n \& \mid r=\& i d=r y f x D w A A Q B A J \& o i=f n d \& p g=P T \& \& d q=P a l l a n t,+J$ .+(2020).+SPSS+survival+manual:+A+step+by+step+guide+to+data+analysis

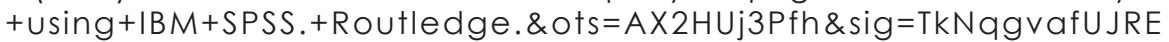
33BbzELQ4Ybuznk [Accessed on 29 June 2019]. 
Papajohn, D., El Asmar, M. and Molenaar, K.R. (2019). Contract administration tools for design-build and construction manager/general contractor highway projects. Journal of Management in Engineering, 35(6): 04019028. https://doi.org/10.1061/(ASCE)ME.1943-5479.0000718.

Rea, L.M. and Parker, R.A. (2014). Designing and Conducting Survey Research: A Comprehensive Guide. 4th Ed. Hoboken, NJ: John Wiley \& Sons, Inc. Available at: https://books.google.com/books?hl=en\&lr=\&id=Ub8BBAAA QBAJ\&oi=fnd \&pg =PA201\&dq=Rea,+L.+M.,+and+Parker, +R.+A.+(2014) .+Designing+and+conducting+survey+research:+\&ots=ix Jzq $1 \mathrm{LhW}$ I\&sig=FPjHgJQqZTQbJljVvaqWQcHmDYs [Accessed on 12 July 2019].

Rowlinson, S. and McDermott, P. (eds.) (2013). Procurement Systems: A Guide to Best Practice in Construction. New York: Routledge.

Saaidin, S.E., Endut, I.R., Samah, S.A.A. and Ridzuan, A.R.M. (2016). The current practice of design and build procurement process in Malaysia. Social and Management Research Journal, 13(2): 81-95. https://doi.org/10.24191/smrj .v13i2.5273.

Saito, T. (2015). Comparative study of design-build procurement between Japan and the US on risk management approach. In B.O. Uwakwhe and I.A. Minkarah (eds.), 10th Symposium Construction Innovation and Global Competitiveness. Boca Raton, FL: CRC Press LLC.

Salim, I.M. and Sulaiman, M. (2013). Examination of the relationship between organisational learning and firm's product innovation. International Journal of Innovation and Learning, 13(3): 254-267. https://doi.org/10.1504/IJIL .2013 .052896 .

Sanvido, V., Grobler, F., Parfitt, K., Guvenis, M. and Coyle, M. (1992). Critical success factors for construction projects. Journal of Construction Engineering Management, 118(1):94-111. https://doi.org/10.1061/(ASCE)0733-9364(1992) 118:1 (94).

Sekar, G., Viswanathan, K. and Sambasivan, M. (2018). Effects of projectrelated and organizational-related factors on five dimensions of project performance: A study across the construction sectors in Malaysia. Engineering Management Journal, 30(4): 247-261. https://doi.org/10.1080/ 10429247.2018.1485000.

Shen, L., Zhang, Z. and Zhang, X. (2016). Key factors affecting green procurement in real estate development: A China study. Journal of Cleaner Production, 153: 372-383. https://doi.org/10.1016/j.jclepro.2016.02.021.

Smith, D. (2014). An introduction to design and building with building information modelling. Journal of Building Information Modelling, 1 (1): 12-14.

Songer, A.D. and Molenaar, K.R. (2007). Model for public sector design-build project selection. Journal of Construction Engineering and Management, 124(6): 467-479. https://doi.org/10.1061/(ASCE)0733-9364(1998)124:6(467).

SPSS Statistics (1997). Guide to Data Analysis. Boston, MA: Addison Wesley.

Taber, K.S. (2018). The use of Cronbach's alpha when developing and reporting research instruments in science education. Research in Science Education, 48: 1273-1296. https://doi.org/10.1007/s $11165-016-9602-2$.

Tsiga, Z., Emes, M. and Smith, A. (2016). Critical success factors for the construction industry. PM World Journal, 5(8): 1-12.

Vaaland, T.I. (2014). Improving project collaboration: Start with the conflicts. International Journal of Project Management, 22(6): 447-454. https://doi .org/10.1016/j.ijproman.2003.11.003. 
Wall, C.J. (1993). The dispute resolution adviser in the construction industry: Implementation for the first time in Hong Kong of the technique of the dispute resolution adviser. Building Research and Information, 21 (2): 122-127. https://doi.org/10.1080/09613219308727272.

Wilkins, J.R. (2011). Construction workers' perceptions of health and safety training programmes. Construction Management Economics, 29(10): 1017-1026. https://doi.org/10.1080/01446193.2011.633538.

Won, J., Lee, G., Dossick, C. and Messner, J. (2013). Where to focus for the successful adoption of building information modeling within the organization. Journal of Construction Engineering and Management, 139(11): 172-182. https://doi.org/10.1061/(ASCE)CO.1943-7862.0000731.

Wong, J.K.W., Chan, J.K. and Wadu, M.J. (2016). Facilitating effective green procurement in construction projects: An empirical study of the enablers. Journal of Cleaner Production, 135: 859-871. https://doi.org/10.1016/j.jclepro .2016 .07 .001

Wong, P.S., Owczarek, A., Murison, M., Kefalianos, Z. and Spinozzi, J. (2014). Driving construction contractors to adopt carbon reduction strategies: An Australian approach. Journal of Environmental Planning and Management, 57(10): 1465-1483. https://doi.org/10.1080/09640568.2013.811402.

Xia, B. and Chan, A.P. (2010). Key competences of design-build clients in China. Journal of Facilities Management, 8(2): 114-129. https://doi.org/10 $.1108 / 14725961011041161$.

Yazan, B. (2014). Three approaches to case study methods in education: Yin, Merriam and Stake. The Qualitative Report, 20(2): 134-152. Available at: https://core.ac.uk/download/pdf/51087783.pdf [Accessed on 12 July 2019].

Yongqiang, C., Xingyu, Z. and Ning, Z. (2013). Comparison of project objectives and factors between DBB and DB in China industrial engineering and innovation. Journal of Industrial Engineering, 3(5): 231-240.

Zhang, X., Shen, L. and WU, Y. (2011). Green strategy for gaining competitive advantage in housing development: A China study. Journal of Cleaner Production, 19(2-3): 157-167. https://doi.org/10.1016/j.jclepro.2010.08.005.

Zhao, X., Hwang, B.G. and Lee, H.N. (2016). Identifying critical leadership styles of project managers for green building projects. International Journal of Construction Management, 16(2): 150-160. https://doi.org/10.1080/1562359 9.2015.1130602.

Zhao, Z.Y., Shen, L.Y. and Zuo, J. (2015). Performance and strategy of Chinese contractors in the international market. Journal of Construction Engineering and Management, 135: 108-118. https://doi.org/10.1061/(ASCE)0733-9364 (2009) 135:2(108). 